\title{
Enzymic Activity of Purified Plasma Membranes from the Yeast and Mycelial forms of Candida albicans
}

\author{
By M. S. MARRIOTT \\ Sub-department of Chemical Microbiology, Department of Biochemistry, \\ Cambridge $C B 2$ I $Q W$
}

(Received 7 March 1975; revised 22 April 1975)

SUM M A R Y

\begin{abstract}
Plasma membranes were isolated from the yeast and mycelial forms of Candida albicans as described previously (Marriott, 1975) and examined for the presence of several enzymes. Measurement of specific activities showed enrichment of $\mathbf{M g}^{2+}$ dependent and $\mathrm{Na}^{+} / \mathrm{K}^{+}$-stimulated $\mathrm{Mg}^{2+}$-dependent adenosine triphosphatase and mannan synthetase, in the plasma membrane fractions from both morphological forms of the organism. However, acid and alkaline phosphatase, NADH oxidase and $5^{\prime}$-nucleotidase showed no such specific location.
\end{abstract}

\section{INTRODUCTION}

Various enzymes have been reported to be specifically located in the plasma membrane fraction of yeasts and other fungi; examples include $\mathrm{Mg}^{2+}$-dependent adenosine triphosphatase (Mg't+-ATPase) (Matile, Moor \& Mühlethaler, 1967), 5'-nucleotidase (AMPase), chitin synthetase (Jan, 1974), phospholipase (Nurminen, Oura \& Suomalainen, 1970) and phosphatidyl inositol kinase (Wheeler, Michell \& Rose, 1972). In many of these reports the enzymes concerned have been assumed to occur in the plasma membrane and the isolation procedure has then been based on these assumptions. An alternative approach has been adopted by Schibeci, Rattray \& Kidby (I973) and Marriott (I975), involving radioactive labelling of the plasma membrane of intact protoplasts. By following the distribution of radioactivity upon fractionation, Marriott (1975) was able to obtain relatively pure preparations of plasma membranes from the yeast and mycelial forms of Candida albicans. In order to confirm and extend these studies, the subcellular location of a number of possible plasma membrane enzymes was investigated. Whilst wall-synthesizing enzymes are likely to be found in the plasma membrane, a situation analogous to that in bacteria (Strominger, 1969), NADH oxidase, located in the endoplasmic reticulum of Ehrlich ascites tumour cells (Kamat \& Wallach, 1965; Wallach \& Kamat, 1966), may not have the same subcellular location in yeasts. Consequeutly, several other enzymes were examined for their possible location in intracellular membranes.

\section{METHODS}

Strains and culture media. Candida albicans 6406, obtained from the Mycological Reference Laboratory, Public Health Service, London, was used throughout. The yeast and mycelial forms were induced using the synthetic media described previously (Marriott, 1975).

Plasma membrane preparation. The modified procedure described by Marriott (1975) for the large-scale preparation of plasma membranes was used (Fig. I). Plasma membranes were 
Lysed protoplasts centrifuged

for $15 \mathrm{~min}$ at $5000 \mathrm{~g}$

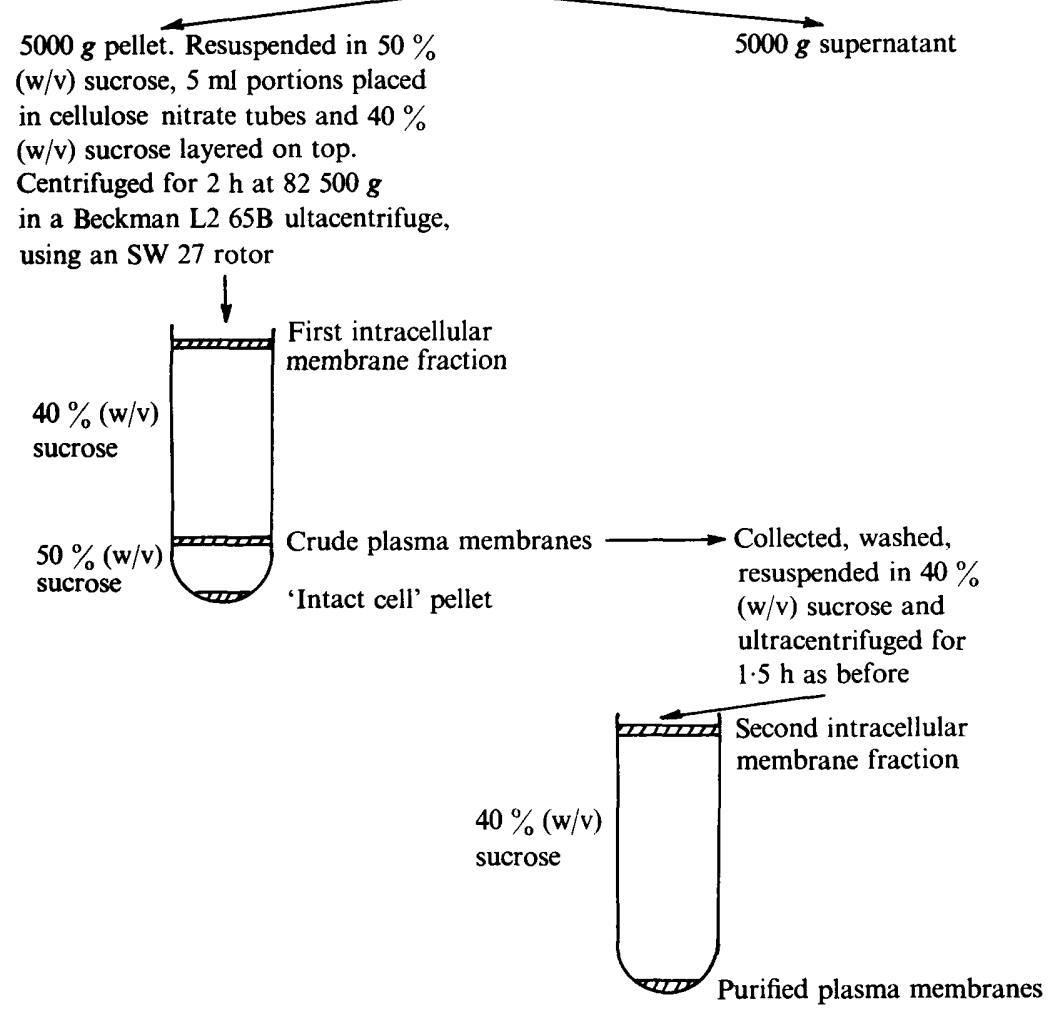

Fig. I. Fractionation procedure used for the isolation of purified plasma membranes from the yeast and mycelial forms of $C$. albicans.

stored at $-20^{\circ} \mathrm{C}$ before the determination of enzymic activity. No decrease in activity was observed during the period of storage $(48 \mathrm{~h})$.

Enzyme activities. Acid phosphatase (EC. 3.1.3.2) was assayed using p-nitrophenol phosphate ( $p$ NPP) as substrate, according to the method of Gezelius (I966). The reaction mixture contained, in a final volume of $3 \mathrm{ml}$ : protein, 50 to $200 \mu \mathrm{g} ; p \mathrm{NPP}, 30 \mu \mathrm{mol}$; sodium

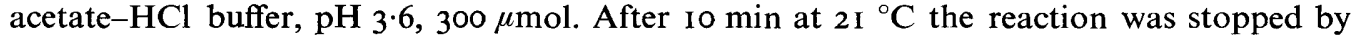
the addition of I M-NaOH $(0.2 \mathrm{ml})$ and the extinction at $420 \mathrm{~nm}$ was measured following centrifugation. The appropriate enzyme and substrate blanks were run simultaneously.

Alkaline phosphatase (EC. 3.I.3.I) was assayed by measuring the release of $p$-nitrophenol from $p$ NPP. A modification of the method of Gezelius \& Wright (1965) was used and the assay mixture contained, in a final volume of $3 \mathrm{ml}$ : protein, 50 to $200 \mu \mathrm{g} ; p \mathrm{NPP}, 30 \mu \mathrm{mol}$; $\mathrm{MgCl}_{2}, 60 \mu \mathrm{mol}$; tris- $\mathrm{HCl}$ buffer $\mathrm{pH} 9 \cdot 0,{ }_{150} \mu \mathrm{mol}$. After Io min at $2 \mathrm{I}{ }^{\circ} \mathrm{C}$ the reaction was stopped by the addition of $10 \%(\mathrm{w} / \mathrm{v})$ trichloracetic acid (TCA) $(0.5 \mathrm{ml})$. The assay mixture was centrifuged, made alkaline with $0.5 \mathrm{ml}$ of $\mathrm{I} \mathrm{M}-\mathrm{NaOH}$ and the $E_{420}$ measured.

NADH oxidase (EC. 1.6.99.3) was assayed by following the oxidation of NADH with potassium ferricyanide as electron acceptor (Wallach \& Kamat, I966). Each assay contained, in a final volume of $3 \mathrm{ml}$ : protein, 50 to $200 \mu \mathrm{g}$; NADH, $0.24 \mathrm{mg}$; potassium ferricyanide, 
$\mathrm{I} \cdot 7 \mu \mathrm{mol}$; tris- $\mathrm{HCl}$ buffer $\mathrm{pH} 7 \cdot 2, \mathrm{r} 50 \mu \mathrm{mol}$. The reaction was started by the addition of NADH and after 10 min at $2 \mathrm{I}{ }^{\circ} \mathrm{C}$ stopped by the addition of $10 \%(\mathrm{w} / \mathrm{v})$ TCA $(0.5 \mathrm{ml})$. The assay mixture was centrifuged and the $E_{340}$ measured.

5'-Nucleotidase (EC. 3. I.3.5) was assayed by measuring the release of inorganic phosphate from disodium AMP (Emmelot et al. 1964). The assay mixture contained, in a final volume of $3 \mathrm{ml}$ : protein, 50 to $200 \mu \mathrm{g}$; AMP, $5 \mu \mathrm{mol}$; tris- $\mathrm{HCl}$ buffer $\mathrm{pH} 7 \cdot 2,50 \mu \mathrm{mol}$. The reaction was started by the addition of enzyme and, after $15 \mathrm{~min}$ at $37^{\circ} \mathrm{C}$, stopped by the addition of $10 \%(\mathrm{w} / \mathrm{v})$ TCA $(0.5 \mathrm{ml})$. After centrifugation, $\mathrm{I} .5 \mathrm{ml}$ of the supernatant was removed and assayed for phosphate using the method of Chen, Toribara \& Warner (I956).

$\mathrm{Mg}^{2+}$-dependent ATPase (EC. 3.6.I.3) was assayed by a modification of the method of Emmelot et al. (1964). The assay mixture contained, in a final volume of $3 \mathrm{ml}$ : protein, 50 to $200 \mu \mathrm{g}$; ATP, $5 \mu \mathrm{mol}$; $\mathrm{MgCl}_{2}$, $15 \mu \mathrm{mol}$; tris- $\mathrm{HCl}$ buffer $\mathrm{pH} 7 \cdot 2,50 \mu \mathrm{mol}$. The reaction was started by the addition of enzyme and stopped after $15 \mathrm{~min}$ at $37^{\circ} \mathrm{C}$ by the addition of I0\% (w/v) TCA $(0.5 \mathrm{ml})$. After centrifugation, I. $5 \mathrm{ml}$ was removed and assayed for phosphate by the method of Chen et al. (I956).

$\mathrm{Na}^{+} / \mathrm{K}^{+}$-stimulated $\mathrm{Mg}^{2+}$-ATPase was assayed by measuring the increase in the amount of phosphate released in the presence of $2 \mu \mathrm{mol} \mathrm{NaCl}$ and $\mathrm{KCl}$. The proportion of $\mathrm{Na}^{+} / \mathrm{K}^{+}$ stimulated activity which was inhibited by ouabain was assayed by adding $50 \mu \mathrm{mol}$ of this inhibitor to the incubation mixture.

Mannan synthetase was assayed by a modification of the procedure described by Algranati, Carminatti \& Cabib (1965) and Behrens \& Cabib (1968). The assay mixture contained, in a final volume of $3 \mathrm{ml}$ : protein, 50 to $200 \mu \mathrm{g}$; GDP-[G-1 $\left.{ }^{14} \mathrm{C}\right] \mathrm{mannose}$ (The Radiochemical Centre, Amersham, Buckinghamshire) specific activity $0.5 \mathrm{mCi} / \mathrm{mmol}, 0.2 \mu \mathrm{mol}$; tris- $\mathrm{HCl}$ buffer $\mathrm{pH} 7 \cdot 2,50 \mu \mathrm{mol}$. The reaction was started by the addition of enzyme and stopped after $90 \mathrm{~min}$ at $37^{\circ} \mathrm{C}$ by the addition of $2 \mathrm{M}-\mathrm{KOH}(0.5 \mathrm{ml})$ and particulate matter was solubilized by boiling for $30 \mathrm{~min}$. Purified $C$. albicans cell wall mannan, $1 \cdot 2 \mathrm{mg}$ (a gift from Dr D. Kerridge, Department of Biochemistry, University of Cambridge) followed by two volumes of absolute ethanol were added. The precipitate was collected by centrifugation at $30000 \mathrm{~g}$ for $15 \mathrm{~min}$ and washed twice with $66 \%(\mathrm{v} / \mathrm{v})$ ethanol. The pellet was resuspended in $50 \mu \mathrm{l}$ water and duplicate samples were removed for radioactive assay. This was carried out using a Packard 3375 liquid scintillation spectrometer, the scintillant being Triton X-Ioo-toluene

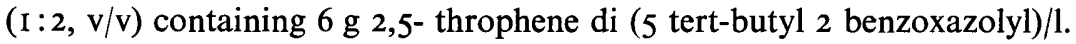

Protein was determined according to the method of Lowry et al. (I95I), using bovine serum albumin as a standard. Insoluble material was solubilized by dispersion in $0.01 \%$ sodium dodecylsulphate.

\section{RESULTS}

Acid phosphatase. The distribution of acid phosphatase upon fractionation of lysed protoplasts from the yeast form of C. albicans is shown in Table I. A large proportion of the activity was sedimented in the $5000 \mathrm{~g}$ pellet, although more than $40 \%$ of the activity remained in the $5000 \mathrm{~g}$ supernatant. Fractionation of the $5000 \mathrm{~g}$ pellet revealed that much of the acid phosphatase activity present was associated with the 'intact cell' pellet and only a small proportion of the activity was found in the crude plasma membrane fraction.

Alkaline phosphatase was distributed evenly between the $5000 \mathrm{~g}$ pellet and supernatant from lysed protoplasts of the yeast form (Table I). However, the specific activity was significantly higher in the supernatant fluid. The amount of activity found in the crude plasma membrane fraction was again low.

NADH oxidase. Table 2 shows the distribution of NADH oxidase after fractionation of 
Tabıe I. Distribution of acid and alkaline phosphatase on fractionation of
protoplasts from the yeast form of C. albicans

The distribution was determined by measuring the release of $p$-nitrophenol from $p$-nitrophenol phosphate. Details of the fractionation procedure are given in Fig. 1. The results are from one experiment only.

\begin{tabular}{|c|c|c|c|c|c|c|}
\hline \multirow[b]{2}{*}{ Fraction } & \multicolumn{3}{|c|}{ Acid phosphatase } & \multicolumn{3}{|c|}{ Alkaline phosphatase } \\
\hline & $\begin{array}{l}\text { Specific } \\
\text { activity* }\end{array}$ & $\begin{array}{c}\text { Total } \\
\text { activity } \\
(\%)\end{array}$ & $\begin{array}{c}\text { Successive } \\
\text { recovery } \\
(\%)\end{array}$ & $\begin{array}{l}\text { Specific } \\
\text { activity* }\end{array}$ & $\begin{array}{c}\text { Total } \\
\text { activity } \\
(\%)\end{array}$ & $\begin{array}{c}\text { Successive } \\
\text { recovery } \\
(\%)\end{array}$ \\
\hline Lysed protoplasts & $I \cdot O$ & 100 & 100 & $I \cdot O$ & 100 & 100 \\
\hline $\begin{array}{l}5000 \mathrm{~g} \text { supernatant } \\
5000 \mathrm{~g} \text { pellet }\end{array}$ & $\begin{array}{l}I \cdot 5 \\
I \cdot 2\end{array}$ & $\left.\begin{array}{l}54 \\
73\end{array}\right\}$ & $\begin{array}{l}127 \dagger \\
100 \dagger\end{array}$ & $\begin{array}{l}\mathbf{I} \cdot 6 \\
0 \cdot 9\end{array}$ & $\left.\begin{array}{l}58 \\
59\end{array}\right\}$ & $\begin{array}{l}\text { II } 7 \dagger \\
\text { IOO† }\end{array}$ \\
\hline $\begin{array}{r}\text { Intracellular } \\
\text { membranes }\end{array}$ & $I \cdot 4$ & II & & $\mathbf{I} \cdot \mathbf{I}$ & 8 & \\
\hline $\begin{array}{l}\text { Crude plasma } \\
\text { membranes }\end{array}$ & $I \cdot 3$ & 3 & $8 I$ & $\mathrm{I} \cdot 3$ & $2\}$ & 76 \\
\hline 'Intact cells' & $I \cdot O$ & 45 & & $I \cdot O$ & $35)$ & \\
\hline
\end{tabular}

* Expressed relative to lysed protoplasts; the absolute values were 18.5 and $31 \cdot 9 \mathrm{nmol} p$-nitrophenol released $/ \mathrm{min} / \mathrm{mg}$ protein, for acid and alkaline phosphatase respectively.

$\dagger$ I 27 (or I I 7) for supernatant and pellet together, and 100 for pellet alone.

\section{Table 2. Distribution of $N A D H$ oxidase on fractionation of protoplasts} from the yeast form of C. albicans

The results were determined by following the oxidation of NADH with potassium ferricyanide as electron acceptor. In this and all subsequent Tables, the results are the means of three experiments and standard deviations are given.

\begin{tabular}{|c|c|c|c|}
\hline Fraction & $\begin{array}{l}\text { Specific } \\
\text { activity* }\end{array}$ & $\begin{array}{l}\text { Total } \\
\text { activity } \\
(\%)\end{array}$ & $\begin{array}{l}\text { Successive } \\
\text { recovery } \\
(\%)\end{array}$ \\
\hline Lysed protoplasts & $I \cdot O$ & 100 & 100 \\
\hline $\begin{array}{l}5000 \mathrm{~g} \text { supernatant } \\
5000 \mathrm{~g} \text { pellet }\end{array}$ & $\begin{array}{l}0.3( \pm 0 \cdot 0) \\
1 \cdot 4 \pm 0 \cdot 1\end{array}$ & $\left.\begin{array}{l}14 \pm 6 \\
92 \pm 3\end{array}\right\}$ & 106 \\
\hline $\begin{array}{l}\text { Intracellular membranes } \\
\text { Crude plasma membranes } \\
\text { 'Intact cells' }\end{array}$ & $\begin{array}{l}0.6 \pm 0.3 \\
0.3 \pm 0.2 \\
I \cdot I( \pm 0.0)\end{array}$ & $\left.\begin{array}{r}5 \pm I \\
I \pm I \\
7 I \pm 6\end{array}\right\}$ & 83 \\
\hline
\end{tabular}

* Expressed relative to lysed protoplasts; a typical absolute value was $37 \cdot \mathrm{I} \mathrm{nmol} \mathrm{NADH} / \mathrm{min} / \mathrm{mg}$ protein.

lysed protoplasts of the yeast form. The major proportion of the activity sedimented at $5000 \mathrm{~g}$ but was not associated with crude plasma membranes.

$5^{\prime}$-Nucleotidase. With yeast protoplasts (Table 3 ), the greater part of the activity was found in the $5000 \mathrm{~g}$ supernatant and there was a 3 - to 4 -fold increase in specific activity in this fraction. The enzyme activity found in the $5000 \mathrm{~g}$ pellet was, on subsequent fractionation, evenly distributed between intracellular membranes and plasma membranes, the specific activity being increased in the former fraction.

With protoplasts from the mycelial form the major proportion of activity was found in the $5000 \mathrm{~g}$ pellet and there was a slight (approximately 2 -fold) increase in specific activity. Most of this activity was found in the crude and purified plasma membrane fractions. However, in terms of specific activity, the enzyme again appeared to have been enriched in the intracellular membrane fractions.

$\mathrm{Mg}^{2+}$-dependent ATPase. Table 4 shows the distribution of $\mathrm{Mg}^{2+}$-dependent ATPase in 
Table 3. Distribution of 5'-nucleotidase activity on fractionation of protoplasts from the yeast and mycelial forms of C. albicans

Results were determined by measuring the release of inorganic phosphate from AMP.

\begin{tabular}{|c|c|c|c|c|c|c|}
\hline \multirow[b]{2}{*}{ Fraction } & \multicolumn{3}{|c|}{ Yeast form } & \multicolumn{3}{|c|}{ Mycelial form } \\
\hline & $\begin{array}{l}\text { Specific } \\
\text { activity* }\end{array}$ & $\begin{array}{l}\text { Total } \\
\text { activity } \\
(\%)\end{array}$ & $\begin{array}{l}\text { Successive } \\
\text { recovery } \\
(\%)\end{array}$ & $\begin{array}{l}\text { Specific } \\
\text { activity* }\end{array}$ & $\begin{array}{l}\text { Total } \\
\text { activity } \\
(\%)\end{array}$ & $\begin{array}{l}\text { Successive } \\
\text { recovery } \\
(\%)\end{array}$ \\
\hline Lysed protoplasts & $I \cdot O$ & 100 & 100 & $I \cdot 0$ & 100 & 100 \\
\hline $\begin{array}{l}5000 \mathrm{~g} \text { supernatant } \\
5000 \mathrm{~g} \text { pellet }\end{array}$ & $\begin{array}{l}3.4 \pm I \cdot 0 \\
0.4 \pm 0 \cdot 1\end{array}$ & $\left.\begin{array}{l}50 \pm 15 \\
20 \pm 7\end{array}\right\}$ & ${ }^{70} 100$ & $\begin{array}{l}0.3 \pm 0.1 \\
1 \cdot 9 \pm 0 \cdot 2\end{array}$ & $\left.\begin{array}{l}10 \pm 3 \\
59 \pm 4\end{array}\right\}$ & ${ }_{100}^{69}$ \\
\hline $\begin{array}{l}\text { Ist intracellular membranes } \\
\text { 'Intact cells' } \\
\text { Crude plasma membranes }\end{array}$ & $\begin{array}{l}2 \cdot I \pm I \cdot 0 \\
\mathrm{ND} \\
0.4 \pm 0 \cdot 2\end{array}$ & $\left.\begin{array}{r}23 \pm 4 \\
\mathrm{ND} \\
7 \pm 2\end{array}\right\}$ & ${ }_{100}^{\mathrm{I} 50}$ & $\begin{array}{l}5 \cdot 5 \pm 0.9 \\
0.9 \pm 0 \cdot 3 \\
2 \cdot 9 \pm 1 \cdot 0\end{array}$ & $\left.\begin{array}{r}4 \pm I \\
2 I \pm 3 \\
I 6 \pm I\end{array}\right\}$ & $\begin{array}{l}69 \\
100\end{array}$ \\
\hline $\begin{array}{l}\text { 2nd intracellular membranes } \\
\text { Purified plasma membranes }\end{array}$ & $\begin{array}{l}5.9 \pm 2.0 \\
0.5 \pm 0.2\end{array}$ & $\left.\begin{array}{l}3 \pm 1 \\
6 \pm 1\end{array}\right\}$ & I 28 & $\begin{array}{l}7 \cdot 4 \pm 2 \cdot 4 \\
2 \cdot 1 \pm 1 \cdot 0\end{array}$ & $\left.\begin{array}{l}1 \pm 1 \\
6 \pm 1\end{array}\right\}$ & 44 \\
\hline
\end{tabular}

* Expressed relative to lysed protoplasts; typical absolute values were 5.9 and $77 \mathrm{nmol}$ phosphate released $/ \mathrm{min} / \mathrm{mg}$ protein, for the yeast and mycelial forms respectively.

\section{Table 4. Distribution of $\mathrm{Mg}^{2+}$-dependent ATPase on fractionation of protoplasts from the yeast and mycelial forms of C. albicans}

Results were determined by measuring the release of inorganic phosphate from ATP.

\begin{tabular}{|c|c|c|c|c|c|c|}
\hline \multirow[b]{2}{*}{ Fraction } & \multicolumn{3}{|c|}{ Yeast form } & \multicolumn{3}{|c|}{ Mycelial form } \\
\hline & $\begin{array}{l}\text { Specific } \\
\text { activity* }\end{array}$ & $\begin{array}{l}\text { Total } \\
\text { activity } \\
(\%)\end{array}$ & $\begin{array}{l}\text { Successive } \\
\text { recovery } \\
(\%)\end{array}$ & $\begin{array}{l}\text { Specific } \\
\text { activity* }\end{array}$ & $\begin{array}{l}\text { Total } \\
\text { activity } \\
(\%)\end{array}$ & $\begin{array}{c}\text { Successive } \\
\text { recovery } \\
(\%)\end{array}$ \\
\hline Lysed protoplasts & $I \cdot O$ & 100 & 100 & $I \cdot O$ & 100 & 100 \\
\hline $\begin{array}{l}5000 \mathrm{~g} \text { supernatant } \\
5000 \mathrm{~g} \text { pellet }\end{array}$ & $\begin{array}{l}0.3 \pm 0.1 \\
1 \cdot 0 \pm 0.3\end{array}$ & $\left.\begin{array}{r}5 \pm I \\
6 I \pm 9\end{array}\right\}$ & ${ }_{100}^{66}$ & $\begin{array}{l}0.8 \pm 0.6 \\
4.0 \pm 0.8\end{array}$ & $\left.\begin{array}{l}21 \pm 5 \\
99 \pm 10\end{array}\right\}$ & 120 \\
\hline $\begin{array}{l}\text { Ist intracellular membranes } \\
\text { 'Intact cells' } \\
\text { Crude plasma membranes }\end{array}$ & $\begin{array}{l}0 \cdot 3 \pm 0 \cdot 1 \\
I \cdot 2 \pm 0 \cdot 3 \\
I \cdot 3 \pm 0 \cdot 2\end{array}$ & $\left.\begin{array}{r}4 \pm I \\
25 \pm 3 \\
27 \pm 4\end{array}\right\}$ & ${ }^{92}$ IOO & $\begin{array}{l}7 \cdot 5 \pm 3 \cdot 2 \\
0 \cdot 9 \pm 0 \cdot 2 \\
8 \cdot 7 \pm I \cdot 0\end{array}$ & $\left.\begin{array}{r}5 \pm 1 \\
14 \pm 2 \\
51 \pm 6\end{array}\right\}$ & $\begin{array}{l}70 \\
100\end{array}$ \\
\hline $\begin{array}{l}\text { 2nd intracellular membranes } \\
\text { Purified plasma membranes }\end{array}$ & $\begin{array}{l}\text { ND } \\
3 \cdot 0 \pm 0.5\end{array}$ & $\left.\begin{array}{r}\text { ND } \\
37 \pm 5\end{array}\right\}$ & $13^{8}$ & $\begin{array}{l}\text { ND } \\
10.6 \pm 0.9\end{array}$ & $\left.\begin{array}{r}\text { ND } \\
34 \pm 4\end{array}\right\}$ & 67 \\
\hline
\end{tabular}

* Expressed relative to lysed protoplasts; typical absolute values were 6.3 and $3.5 \mathrm{nmol}$ phosphate released $/ \mathrm{min} / \mathrm{mg}$ protein, for the yeast and mycelial forms respectively.

the subcellular fractions derived from the yeast and mycelial forms. In both instances, most of the activity was associated with the $5000 \mathrm{~g}$ pellet, being evenly distributed between 'intact cell' and crude plasma membrane fractions. All of the latter activity was found in purified plasma membranes, the specific activity being slightly higher in the crude plasma membrane fraction and increasing still further in purified plasma membranes. A similar pattern was observed with the mycelial form; again, from the increase in specific activity, the enzyme appeared to be located in the purified plasma membrane fraction.

The $\mathrm{Na}^{+} / \mathrm{K}^{+}$-stimulated $\mathrm{Mg}^{2+}$-ATPase distributions are shown in Table 5. The specific activity of the enzyme was higher in both plasma membrane fractions and to a lesser extent in the intracellular membrane fractions. Ouabain inhibited the $\mathrm{Na}^{+} / \mathrm{K}^{+}$-stimulated activity in the various fractions to a variable extent ( 0 to $70 \%$ ). Only that activity in the two purified plasma membrane fractions was totally inhibited by this compound. 
Table 5. Distribution of $\mathrm{Na}^{+} / \mathrm{K}^{+}$-stimulated $\mathrm{Mg}^{2+}-\mathrm{ATP}$ ase activity on fractionation of protoplasts from the yeast and mycelial forms of $C$. albicans

Results were determined by measuring the increase in release of inorganic phosphate from ATP.

\begin{tabular}{|c|c|c|c|c|c|c|}
\hline \multirow[b]{2}{*}{ Fraction } & \multicolumn{3}{|c|}{ Yeast form } & \multicolumn{3}{|c|}{ Mycelial form } \\
\hline & $\begin{array}{l}\text { Specific } \\
\text { activity* }\end{array}$ & $\begin{array}{c}\text { Total } \\
\text { activity } \\
(\%)\end{array}$ & $\begin{array}{l}\text { Successive } \\
\text { recovery } \\
(\%)\end{array}$ & $\begin{array}{l}\text { Specific } \\
\text { activity* }\end{array}$ & $\begin{array}{l}\text { Total } \\
\text { activity } \\
(\%)\end{array}$ & $\begin{array}{l}\text { Successive } \\
\text { recovery } \\
(\%)\end{array}$ \\
\hline Lysed protoplasts & $I \cdot 0$ & 100 & 100 & $1 \cdot 0$ & 100 & 100 \\
\hline $\begin{array}{l}5000 \mathrm{~g} \text { supernatant } \\
5000 \mathrm{~g} \text { pellet }\end{array}$ & $\begin{array}{l}I \cdot 9 \pm I \cdot 0 \\
I \cdot 0 \pm 0 \cdot 2\end{array}$ & $\left.\begin{array}{l}28 \pm 8 \\
59 \pm 9\end{array}\right\}$ & ${ }_{100}^{87}$ & $\begin{array}{l}0.1 \pm 0.1 \\
4.2 \pm 3.0\end{array}$ & $\left.\begin{array}{c}2 \pm 1 \\
107 \pm 10\end{array}\right\}$ & $\log _{100}$ \\
\hline $\begin{array}{l}\text { Ist intracellular membranes } \\
\text { 'Intact cells' } \\
\text { Crude plasma membranes }\end{array}$ & $\begin{array}{l}0 \cdot 2 \pm 0 \cdot 1 \\
0 \cdot 2 \pm 0 \cdot 1 \\
3 \cdot 5 \pm 0 \cdot 1\end{array}$ & $\left.\begin{array}{r}3 \pm I \\
5 \pm I \\
70 \pm 7\end{array}\right\}$ & ${ }_{100}^{132}$ & $\begin{array}{r}9 \cdot 0 \pm 3 \cdot 0 \\
1 \cdot 3 \pm 0 \cdot 4 \\
12 \cdot 0 \pm 2 \cdot 0\end{array}$ & $\left.\begin{array}{c}6 \pm 2 \\
22 \pm 7 \\
71 \pm 10\end{array}\right\}$ & ${ }_{100}^{93}$ \\
\hline $\begin{array}{l}\text { 2nd intracellular membranes } \\
\text { Purified plasma membranes }\end{array}$ & $\begin{array}{l}I \cdot 9 \pm 0 \cdot 3 \\
6 \cdot 0 \pm 0 \cdot 6\end{array}$ & $\left.\begin{array}{c}I( \pm 0) \\
83 \pm 6\end{array}\right\}$ & $\mathrm{I} 20$ & $\begin{array}{r}2 \cdot I \pm I \cdot 0 \\
13 \cdot 0 \pm I \cdot 5\end{array}$ & $\left.\begin{array}{r}I \pm I \\
42 \pm 4\end{array}\right\}$ & 60 \\
\hline
\end{tabular}

* Expressed relative to lysed protoplasts; typical absolute values were 19.7 and 3.4 nmol phosphate released $/ \mathrm{min} / \mathrm{mg}$ protein, for the yeast and mycelial forms respectively.

Table 6. Distribution of mannan synthetase on fractionation of protoplasts from the yeast and mycelial forms of C. albicans

Results were determined by measuring the incorporation of $\left[\mathrm{G}-{ }^{14} \mathrm{C}\right]$-mannose intomannan from GDP-[G-14 $\mathrm{C}]$ mannose.

\begin{tabular}{|c|c|c|c|c|c|c|}
\hline \multirow[b]{2}{*}{ Fraction } & \multicolumn{3}{|c|}{ Yeast form } & \multicolumn{3}{|c|}{ Mycelial form } \\
\hline & $\begin{array}{l}\text { Specific } \\
\text { activity* }\end{array}$ & $\begin{array}{l}\text { Total } \\
\text { activity } \\
(\%)\end{array}$ & $\begin{array}{l}\text { Successive } \\
\text { recovery } \\
(\%)\end{array}$ & $\begin{array}{l}\text { Specific } \\
\text { activity* }\end{array}$ & $\begin{array}{l}\text { Total } \\
\text { activity } \\
(\%)\end{array}$ & $\begin{array}{l}\text { Successive } \\
\text { recovery } \\
(\%)\end{array}$ \\
\hline Lysed protoplasts & $1 \cdot 0$ & 100 & 100 & $1 \cdot 0$ & 100 & 100 \\
\hline $\begin{array}{l}5000 \mathrm{~g} \text { supernatant } \\
5000 \mathrm{~g} \text { pellet }\end{array}$ & $\begin{array}{l}2 \cdot 0 \pm 0 \cdot 5 \\
1 \cdot 8 \pm 0 \cdot 1\end{array}$ & $\left.\begin{array}{r}28 \pm 7 \\
100 \pm 8\end{array}\right\}$ & ${ }^{128} 100$ & $\begin{array}{l}0 \cdot 6 \pm 0 \cdot 1 \\
3 \cdot 4 \pm 1 \cdot 0\end{array}$ & $\left.\begin{array}{l}18 \pm 1 \\
87 \pm 10\end{array}\right\}$ & ${ }_{100}^{105}$ \\
\hline $\begin{array}{l}\text { Ist intracellular membranes } \\
\text { 'Intact cells' } \\
\text { Crude plasma membranes }\end{array}$ & $\begin{array}{l}I \cdot 3 \pm 0 \cdot I \\
I \cdot 3 \pm 0 \cdot 2 \\
2 \cdot 7 \pm 0 \cdot 3\end{array}$ & $\left.\begin{array}{l}15 \pm I \\
29 \pm 4 \\
54 \pm 6\end{array}\right\}$ & ${ }^{98} \mathrm{I} 00$ & $\begin{array}{l}1 \cdot 8 \pm 0 \cdot 4 \\
I \cdot 8 \pm 0 \cdot 5 \\
3 \cdot 7 \pm 0 \cdot 3\end{array}$ & $\left.\begin{array}{r}2 \pm I \\
29 \pm 5 \\
21 \pm 2\end{array}\right\}$ & $\begin{array}{l}60 \\
100\end{array}$ \\
\hline $\begin{array}{l}\text { 2nd intracellular membranes } \\
\text { Purified plasma membranes }\end{array}$ & $\begin{array}{l}0.8 \pm 0.3 \\
3.7 \pm 0.5\end{array}$ & $\left.\begin{array}{c}0 \cdot 2 \pm 0 \cdot I \\
49 \pm 9\end{array}\right\}$ & 9 I & $\begin{array}{l}2 \cdot 6 \pm 0 \cdot 7 \\
7 \cdot 5 \pm 0 \cdot 7\end{array}$ & $\left.\begin{array}{c}0.3 \pm 0.1 \\
24 \pm 4\end{array}\right\}$ & I 16 \\
\hline
\end{tabular}

* Expressed relative to lysed protoplasts; typical absolute values were $0.7 \times 10^{3}$ and $1 \cdot 8 \times 10^{3}$ c.p.m. incorporated $/ \mathrm{min} / \mathrm{mg}$ protein, for the yeast and mycelial forms respectively.

Mannan synthetase. Most of the activity was sedimented at $5000 \mathrm{~g}$ in both cases and was distributed evenly between 'intact cell' and crude plasma membrane fractions (Table 6). Most of the activity found in the latter fraction was also found in the purified plasma membrane fraction upon further fractionation. The specific activity of this enzyme was highest in both plasma membrane fractions but particularly in those from the mycelial form.

\section{DISCUSSION}

There have been a number of reports on the subcellular location of enzymes in yeasts, particularly for Saccharomyces cerevisiae. The techniques employed have generally involved differential and/or density gradient centrifugation. It is mainly the separation and characterization of organelles such as mitochondria (Schatz, 1963; Schatz \& Klima, I964; Perlman \& 
Mahler, 1970), vacuoles (Matile \& Wiemken, 1967) and peroxisomes (Avers \& Federman, I968) which have been reported.

Cartledge \& Lloyd (197I) fractionated protoplasts from Saccharomyces carlsbergensis using zonal centrifugation and found acid phosphatase to be located in a variety of membranous vesicles with different buoyant densities. In the present investigation, neither acid nor alkaline phosphatase showed a specific localization after fractionation of protoplasts from the yeast form of $C$. albicans. However, it would appear that little if any activity was associated with the plasma membrane fraction. Similarly, NADH oxidase was not detected in plasma membrane preparations to any appreciable extent, nor was succinate dehydrogenase (Marriott, 1975).

5 -Nucleotidase has been reported as being enriched in plasma membranes from the fungus Phycomyces blakesleeanus (Jan, 1974). With C. albicans no such specific location of this enzyme was observed (Table 3). Recoveries of enzymic activity greater than $100 \%$ are reported in several Tables in this paper. The reasons for this probably include removal of specific inhibitors and increased substrate penetration due to mechanical disruption during fractionation. Also the large proportion of activity found in the 'intact cell' pellet is likely to be caused by the presence of trapped membrane fragments, since more than $95 \%$ of the original protoplast suspension was sensitive to osmotic lysis.

Most of the $\mathrm{Mg}^{2+}$-dependent ATPase activity from lysed protoplasts of either form of C. albicans was sedimented at $5000 \mathrm{~g}$ (Table 4). A proportion of this ( 27 to $5 \mathrm{I} \%$ of total activity) was found associated with the crude plasma membrane fractions. Further centrifugation did not lead to a significant redistribution of the enzyme, and some enrichment (3- to Io-fold) was observed in purified plasma membrane preparations.

A similar distribution pattern was observed with $\mathrm{Na}^{+} / \mathrm{K}^{+}$-stimulated $\mathrm{Mg}^{2+}$-ATPase activity, with the major proportion of the enzyme activity sedimenting at $5000 \mathrm{~g}$. Approximately $70 \%$ of the total activity of this enzyme was located in the crude plasma membrane fractions, and in terms of specific activity the enzyme was enriched 6-to I3-fold in the purified plasma membrane fractions from the two forms of the organism.

Mannan synthetase, an enzyme involved in cell wall synthesis, is likely to be located in the plasma membrane of yeasts (Behrens \& Cabib, I968). A significant proportion, 21 to $54 \%$ of the total activity, was found in the crude plasma membrane fractions. Enrichment of the enzyme (4- to 7 -fold) occurred in the purified plasma membrane fractions, indicating that mannan synthetase is mainly located in these preparations.

In conclusion, it would appear that acid and alkaline phosphatase, NADH oxidase and 5 -nucleotidase are not specifically located in the plasma membrane of $C$. albicans. On the other hand ouabain-inhibitable $\mathrm{Mg}^{2+}$-dependent ATPase, $\mathrm{Na}^{+} / \mathrm{K}^{+}$-stimulated $\mathrm{Mg}^{2+}$ ATPase, and mannan synthetase do seem to have a subcellular location in this membrane.

I am grateful to the Medical Research Council for providing financial support and to Dr D. Kerridge for help in the preparation of the manuscript.

\section{REFERENCES}

Algranati, I. D., Carminatti, H. \& Cabib, E. (1965). The enzymic synthesis of yeast mannan. Biochemical and Biophysical Research Communications 12, 504-509.

Avers, C. \& Federman, M. (1968). The occurrence in yeast of cytoplasmic granules which resemble microbodies. Journal of Cell Biology 37, 555-559.

Behrens, N. H. \& CABIB, E. (1968). The biosynthesis of mannan in Saccharomyces carlsbergensis. Journal of Biological Chemistry 243, 502-509. 
Cartledge, T. \& Lloyd, D. (197I). Subcellular fractionation by differential and zonal centrifugation of aerobically grown glucose-depressed Saccharomyces carlsbergensis. Biochemical Journal r26, 38 I-393.

Chen, P. S., Toribara, T. Y.\& WARNer, H. (1956). Microdetermination of phosphorus. Analytical Chemistry 28, I $756-1758$.

Emmelot, P., Bos, C. T., Benedetti, E. L. \& Rumke, P. H. (1964). Studies on plasma membranes. I. Chemical composition and enzyme content of plasma membranes isolated from rat liver. Biochimica et biophysica acta 90, I26-I45.

Gezelius, K. (1966). Acid phosphatase in Dictyostelium discoideum. Physiologia plantarum 19, 946-959.

Gezelius, K. \& WRIGHT, B. E. (1965). Alkaline phosphatase in Dictyostelium discoideum. Journal of General Microbiology 38, 309-327.

JAN, Y. N. (1974). Properties and cellular localization of chitin synthetase in Phycomyces blakesleeanus. Journal of Biological Chemistry 249, 1973-I979.

Kamat, V. B. \& Wallach, D. F. H. (1965). Separation and partial purification of plasma membrane fragments from Ehrlich ascites carcinoma microsomes. Science, New York 148, 1343-1345.

Lowry, O. H., Rosebrough, N. J., Farr, A. C. \& Randall, R. J. (195I). Protein measurement with the Folin phenol reagent. Journal of Biological Chemistry r93, 265-275.

MARRIOTT, M. S. (1975). Isolation and chemical characterization of plasma membranes from the yeast and mycelial forms of Candida albicans. Journal of General Microbiology 86, I I 5-I 32.

Matile, P., MoOR, H. \& MüHlethaleR, K. (1967). Isolation and properties of plasmalemma in yeast. Archiv für Mikrobiologie 58, 20I-2II.

Matile, P. \& Wiemken, A. (I967). The vacuole as the lysosome of the yeast cell. Archiv für Mikrobiologie 56, I $48-$ I 55.

Nurminen, T., Oura, E. \& Suomalainen, H. (I970). The enzymic composition of the isolated cell wall and plasma membrane of baker's yeast. Biochemical Journal Ir6, 6I-69.

Perlman, P. \& Mahler, H. (1970). Intracellular localization of enzymes in yeast. Archives of Biochemistry and Biophysics 136, 245-259.

Schatz, G. (1963). The isolation of possible mitochondrial precursor structures from aerobically grown baker's yeast. Biochemical and Biophysical Research Communications 12, 448-45I.

SchatZ, G. \& Klima, J. (1964). Triphosphopyridine nucleotide: cytochrome C reductase of Saccharomyces cerevisiae, a microsomal enzyme. Biochimica et biophysica acta 81, 448-46I.

SChibeCI, A., RATTRAy, J. B. M. \& KIDBY, D. K. (1973). Isolation and identification of yeast plasma membrane. Biochimica et biophysica acta 31r, I 5-25.

Strominger, J. (1969). Penicillin-sensitive enzymatic reactions in bacterial cell wall synthesis. Harvey Lectures 64, $179-2 \mathrm{I} 3$.

Wallach, D. F. H. \& Kamat. V. B. (I966). Preparation of plasma membrane fragments from ascites tumor cells. In Methods in Enzymology, vol. 8, pp. I64-I 72. Edited by E. Neufeld and V. Ginsburg. New York and London: Academic Press.

Wheeler, G., Michell, R. \& Rose, A. H. (1972). Phosphatidyl inositol kinase activity in Saccharomyces cerevisiae. Biochemical Journal 127, $64 \mathrm{P}$. 